\title{
漸增負荷テストにおける呼気ガス動態のシステムダイナミクスモデリング
}

\author{
高橋 信二 1) 林 容市 ${ }^{11}$ 西嶋 尚彦
}

\section{System dynamics modeling of expired gas dynamics during incremental test}

\author{
Shinji Takahashi', Youichi Hayashi ${ }^{1}$ and Takahiko Nishijima ${ }^{2}$
}

\begin{abstract}
A study was conducted to examine the validity of the system dynamics (SD) model of expired gas dynamics during incremental tests, individually. In modeling, it was assumed that (1) the increment of exercise intensity follows the test time, (2) the behavior of oxygen uptake $\left(\mathrm{V}_{2}\right)$ and lactate (La) depend on exercise intensity, (3) $\mathrm{CO}_{2}$ output $\left(\mathrm{VCO}_{2}\right)$ is the sum of metabolic $\dot{\mathrm{V}} \mathrm{CO}_{2}$ that stems from increased $\dot{\mathrm{V}} \mathrm{O}_{2}$ and $\dot{\mathrm{VCO}}_{2}$ generated by buffering $\mathrm{La}$, and (4) ventilation $\left(\dot{\mathrm{V}}_{\mathrm{E}}\right)$ is the sum of ventilation and hyperventilation that depends on $\mathrm{La}$. The validity of the model was examined by (a) determination coefficient $\left(\mathrm{r}^{2}\right)$ as a fit index of simulated $\dot{\mathrm{V}}_{\mathrm{E}}, \dot{\mathrm{VO}}_{2}, \dot{\mathrm{V}}_{2}$ and La to measured them, (b) equivalence consisting of the correlation coefficient $(r)$ and paired $t$ test between simulated and measured data at the anaerobic threshold (AT) and respiratory compensation point (RCP). Seven male subjects performed two protocol types of incremental tests to exhaustion on a cycle ergometer (TEST I, TEST II). The measurements in TEST I were used for modeling, and TEST II measurements for estabishing the validity criteria of the model. In all subjects, the fit index of the simulated $\dot{\mathrm{V}}, \dot{\mathrm{V}} \mathrm{O}_{2}, \dot{\mathrm{V}} \mathrm{VO}_{2}$ and La was high $\left(\mathrm{r}^{2}=\right.$ more than $\left.0.954, \mathrm{P}<.05\right)$. Correlation coefficients of simulated $\dot{\mathrm{VO}}_{2}, \% \dot{\mathrm{VO}}_{2} \max$ and Watt at AT and RCP were respectively high $(\mathrm{P}<.05)$, and mean differences between simulated and measured $\dot{\mathrm{V}}_{2}, \% \dot{\mathrm{V}} \mathrm{O}_{2}$ max and Watt at $\mathrm{AT}$ and RCP were not statistically significant. These results indicated that the SD model of expired gas dynamics during incremental testing was valid. In conclusion, it is suggested that individual aerobic fitness can be analytically evaluated using SD modeling with incremental test measures.
\end{abstract}

Key words : simulation, aerobic fitness, system dynamicszing parts of speech (Japan J. Phys. Educ. Hlth. Sport Sci. 48: 169-180, March, 2003)

1) 筑波大学体学科学研究科

干 305-8574 茨城県つくばけ天古台1-1-1

2) 筑波大学体青科学:系

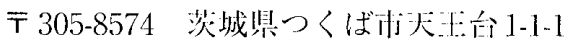

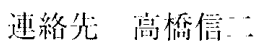

1. University of Tsukuba, Doctoral Program of Health and Sport Sciences

1-1-1 Tennodai Tsukuba city, Ibaraki 305-8574

2. University of T'sukuba, Institute of Health and Sport Sciences

748 1-1-1 Tennodai Tsukuba city, Ibaraki 305-8574

Corresponding author shinji@stat.laiktu.tsukuba.ac.jp 
キーワード：シミュレーション, 全身持久性, シ ステムダイナミクス

\section{I 緒言}

効果的な全身持久性トレーニングを実施するた めには, 処方された運動の強度と代謝機能の改善 との間の関係を個々人について確認することが求 められる。トレーニング効果は運動強度に最も依 存し（McArdle et al., 1991）, 物理的強度, 生理 的強度および心理的強度などの指標を用いて記述 される。全身持久性は，一般的に最大酸素摂取量 $\left(\mathrm{VO}_{2} \mathrm{max}\right)$ ，無酸素性代謝閾值（anaerobic threshold : AT), $\mathrm{VO}_{2} \max$ の相対的強度（\% $\mathrm{VO}_{2} \max$ ），血中乳酸濃度（La）抢よび心拍数な どの生理的指標を用いて評䛧される。これらの生 理的指標は運動強度に対応して，非線形な変動を 示すことが知られており，時系列に変動する生理 的指標の動態の分析には動的モデリング技法が適 用されてきている。

Morton and Gregory（1987）は，定常負荷テ ストに扔ける被験者毎の $\mathrm{VO}_{2}$ 動態に指数関数モデ ルを適用し， $\mathrm{VO}_{2}$ の時定数は年齢，トレーニング 状沅に影響されることを明らかにした．指数関数 モデルを適用した他の負荷テストでは，Hughson et al. (1988), Miyamoto and Niizeki (1992) は 漸増負荷テストおよび漸減負荷テストにおける仕 事量の増減と $\mathrm{VO}_{2}$, 換気量 $\left(\mathrm{V}_{\mathrm{E}}\right)$, 二酸化炭素排 出量 $\left(\mathrm{VCO}_{2}\right)$, 心拍数の動態との関係を検討した。 また，Hughson et al.（1990）はフーリエ解析を 用い，ランダム負荷テスト中の $\mathrm{VO}_{2}$ 動態をシステ ムとして取り扱うことを試みた. Sherrill et al. （1990）は漸增負荷テストに抄ける $\mathrm{VO}_{2}$ 動態と $\mathrm{VCO}_{2}$ 動態に多項式スプライン関数モデルを適用 L, AT と代償性呼吸の開始点 (respiratory compensation point：RCP）の判定に有用性の 高いモデルを報告した. Cabrera and Chizeck （1996）は動的な因果関係を仮定した多変量時系 列モデルを漸増負荷に対する $\mathrm{VO}_{2}$ 動態，La動態 に適用し，雨变数の関係性を考察した。これらの 方程式の多くは非線形最小二乗法あるいは最尤法
を用いて負荷運動過程に扮ける呼気ガス諸量間の 因果関係をモデリングし， $\mathrm{VO}_{2}$ に対する $\mathrm{VCO}_{2} や$ Laの関係を求めたものであり，呼気ガス諸量の 動態を十分に説明するモデルであると考えられ る。また，Billat et al. (2000) は指数関数モデル を $\mathrm{VO}_{2}$ 動態に適用し，運動遂行に対する無気的代 謝の貢献度の評価方法を報告しており，個別的な 全身持久性の評価方法としての有用性の高さが示 されている。

一方, Di Prampero (1981) Wasserman et al. (1986) Whipp and Wasserman (1972) Whipp et al.（1989）などが構築した概念モデルでは, 運動強度に対する生理的応答を示す $\mathrm{V}_{\mathrm{E}}, \mathrm{VO}_{2}$, $\mathrm{VCO}_{2}, \mathrm{La}$ などの各变数間には動的な因果関係が 仮定されているものの，上述の数理モデルは直接 的かつ包括的に因果関係を取り扱ったものではな く，变数間の動的因果関係が取り扱われないため に，全身持久性指標間の関係性を十分に把握する ことができるとは言い難い。

多変数から構成される動的な因果関係を検討す る手法として，近年システムダイナミクスモデリ ングが適用されてきている（Bowker，1993；福 田ら，1993；島田ら，1994）。システムダイナミ クスは動的シミュレーション技法であり，対象と する現象の変動をシステムとして捉え, 時間経過 に伴い集積する量を表すストック，ストックの単 位時間あたりの変化量を表すフロー，フローの意 志決定に情報を提供するコンバータ，フィードバ ックループおよび遅れ時間によりシステムを構成 し，変数間の相互依存関係を構造化する手法であ る.

負荷運動過程に扔ける生理的指標間にみられる 動的因果関係にシステムダイナミクスを適用する ことにより，個体内の代謝機能をシステムと捉え， 呼気ガス諸量間に見られる動的因果構造に基つい て呼気ガス動態を動的シミュレーションモデルと して取り扱うことができる。これによって，個々 人についてモデリングし，負荷運動過程に拈ける $\mathrm{VO}_{2}$ や $\mathrm{VCO}_{2}$ をシュレーションすることができ， RMR (relative metabolic rates) や Mets (metabolic equivalents）などの代謝量の指標を個人毎 
に予測可能となり，任意に行われるトレーニング 量の，個別性を重視した計量化が期待できる。ま たシステムダイナミクスの適用により，全身持 久性の発達を呼気ガス諸量間の相互依存関係の変 化として構造モデルに表現することができ，新た な全身持久性の評価方法として用いることも期街 される。

そこで本研究は,多様な負荷運動過程に扔いて, 呼気ガス動態を子測するモデルの作成のための第 一段階として，一般的なテス卜方法である漸増傎 荷運動に言及し，漸増負荷テストで測定される生 理的指標間の動的因果関係にシステムダイナミク スモデリングを適用して呼気ガス動態モデルを構 築する。構築されたモデルの妥当性は適合性掞よ び等㜀性から検証すること，およびシステムダイ ナミクスモデリングを用いた全身持久性の新しい 評枿方法を検傠することを目的とした。

\section{II方法}

\section{1. 被験者}

大学生ラグビー部員男子7名を被験者とした。 被験者の年齢，身長，体重，競技歴の平均值士標 準偏差は，それぞれ $21.3 \pm 0.95$ 歳， $173 \pm 4.16$ $\mathrm{cm}, 75.9 \pm 10.5 \mathrm{~kg}, 6.3 \pm 0.76$ 年であった。被験 者に研究内容を十分に理解させたうえで，実験参 加への承諾を得た。

表 1 は，測定項目の平均值掞よび標準偏美を示
している。 $\mathrm{VO} \max は 4007 \pm 465 \mathrm{ml} / \mathrm{min} て ゙ あ り ，$ 体重あたりでの $\mathrm{VO}_{2} \max \left(\mathrm{V} \mathrm{O}_{2} \max / \mathrm{W}\right)$ は53.1 $5.1 \mathrm{ml} / \mathrm{kg} / \mathrm{min}$ であった。 $\mathrm{VO}_{2} \mathrm{AT}$ は $2190 \pm$ $358.0 \mathrm{ml} / \mathrm{min}, \quad \mathrm{VO}_{2} \mathrm{RCP}$ は $3445 \pm 506.7 \mathrm{ml} / \mathrm{min}$ で あり，AT時およびRCP時の $\mathrm{VO}_{2}$ max に刘する相 対值 $\left(\% \mathrm{VO}_{2} \max\right.$ at $\mathrm{AT}, \% \mathrm{VO}_{2} \max$ at $\left.\mathrm{RCP}\right)$ は $55.1 \pm 10.0 \% ， 85.9 \pm 6.3 \%$ あった。また $\mathrm{VO}_{2} \max$ が得られた仕事量 (Watts at $\mathrm{VO}_{2} \max$ ), AT 時の仕事量（Watts at AT），RCP時の仕事 量（Watts at RCP）はそれぞれ，294 24 watts, $156 \pm 19$ watts, $244 \pm 31$ wattsであった。

\section{2. モデリングの手続き}

Bowker（1993）の手続きを応用し，システム ダイナミクス・シミュレーションソフトウェア STELLA（Ver. 5.1J）を用いて，各被験者につい て漸増負荷運動中における生理的応答をモデリン グした。手続きは，(1)モデルの概念化，(2)モデル の作成，(3漸増負荷テスト，(4)シミュレーション， (5)モデルの評価：再現性, 適合性, 等価性の検証, である。

\section{3. モデルの概念化}

生体反応の多くはフィードバックが作用する。 連動中にみられる代謝応答にもフィードバックが 作用すると考えられる。すなわち，連動に要求さ れるエネルギー需要量に対する運動初期の供給量 の不足がエネルギー供給を促進させる. その後，

Table 1 Anthropometric characteristics and aerobic capacities of subjects

\begin{tabular}{|c|c|c|c|c|c|c|c|c|c|c|c|c|c|}
\hline \multirow[t]{2}{*}{ Subjects } & \multirow{2}{*}{$\begin{array}{c}\text { Age } \\
\text { (yrs) }\end{array}$} & \multirow{2}{*}{$\underset{(\mathrm{cm})}{\text { Height }}$} & \multirow{2}{*}{$\begin{array}{c}\text { Weight } \\
(\mathrm{kg})\end{array}$} & \multirow{2}{*}{$\begin{array}{c}\% \mathrm{Fat} \\
(\%)\end{array}$} & \multicolumn{3}{|c|}{$\operatorname{Max}$} & \multicolumn{3}{|c|}{$\mathrm{AT}$} & \multicolumn{3}{|c|}{$\mathrm{RCP}$} \\
\hline & & & & & $(\mathrm{ml} / \mathrm{kg} / \mathrm{min})$ & $(\mathrm{ml} / \mathrm{min})$ & (watt) & $(\mathrm{ml} / \mathrm{min})$ & $(\%)$ & (watt) & $(\mathrm{ml} / \mathrm{min})$ & $(\%)$ & (watt) \\
\hline $\mathrm{HN}$ & 20 & 174 & 75.9 & 11.3 & 60.8 & 4613 & 300 & 2163 & 46.9 & 150 & 4205 & 91.2 & 270 \\
\hline TK & 22 & 176 & 83.1 & 13.4 & 45.7 & 3796 & 285 & 2011 & 53.0 & 150 & 3141 & 82.7 & 225 \\
\hline $\mathrm{KK}$ & 22 & 176 & 74.5 & 13.3 & 55.0 & 4094 & 315 & 1684 & 41.1 & 135 & 3069 & 75.0 & 240 \\
\hline $\mathrm{RM}$ & 21 & 171 & 62.0 & 9.8 & 52.5 & 3252 & 255 & 1885 & 58.0 & 135 & 2995 & 92.1 & 210 \\
\hline $\mathrm{KJ}$ & 22 & 176 & 94.4 & 20.0 & 47.6 & 4490 & 315 & 2417 & 53.8 & 165 & 4021 & 89.6 & 285 \\
\hline YY & 22 & 176 & 73.6 & 10.4 & 55.2 & 4063 & 315 & 2473 & 60.9 & 180 & 3636 & 89.5 & 270 \\
\hline $\mathrm{AF}$ & 20 & 165 & 67.9 & 11.5 & 55.1 & 3742 & 270 & 2697 & 72.1 & 180 & 3047 & 81.4 & 210 \\
\hline mean & 21.3 & 173 & 75.9 & 12.8 & 53.1 & 4007 & 294 & 2190 & 55.1 & 156 & 3445 & 85.9 & 244 \\
\hline SD & 0.95 & 4.16 & 10.5 & 3.44 & 5.11 & 465 & 24 & 358 & 9.99 & 19 & 507 & 6.34 & 31 \\
\hline
\end{tabular}


供給量と需要量の差が減少するにしたがい，エネ ルギー供給系の促進は緩やかになり，その後，定 常状態に達する.すなわち, 連動初期においては, エネルギー供給の規定因子であるエネルギー供給 量と需要量の差が，時間経過に伴い変動するエネ ルギー供給により決定されるというフィードバッ ク関係にある。しかしながら，本研究では，漸増 負荷という特殊な運動過程の呼気ガス動態を取り 扱ったものであり，呼気ガス動態の規定因子とな る仕事量は，呼気ガス動態に影響されず単調湖増 する。したがって，本研究では，桷増負街テスト 過程における呼気ガス動態を仕事量の規定因子と しない，すなわち仕事量と呼気がス動態間にフィ ードバック関係を構築しないモデルを仮定し，モ デリングを行った。

Di Prampero (1981), Wasserman et al. (1986) Whipp et al.（1989）の概念にしたがい，図1に 示されるような因果関係の概念モデルを仮定し た，仮定された条件は，以下の5点であった。(1) 時間経過に伴い仕事量は漸增する。(2)仕事量の増 加に伴い， $\mathrm{V} O$ はレベリングオフが見られるまで 増加し， $\dot{\mathrm{VO}}$ の増加に対応して有気的代謝由来の 代謝性 $\mathrm{VCO}_{2}$ は増加する。 (3)仕事量の増加に対し て Laは非直線的に増加し, 過剩蓄積する Laは緩 衝作用に由来する緩衝性 $\mathrm{VCO}$ の増加を引き起こ す。したがって，(4) $\mathrm{VCO}_{2}$ は代謝性 $\mathrm{VCO}_{2}$ と緩衝 性 $\mathrm{VCO}_{2}$ の和である。（5) $\mathrm{V}_{1:}$ は $\mathrm{VCO}_{2}$ に比例して増 加し, RCP 以上では $\mathrm{La}$ の過剩蓄積に起因する代 謝性アシドーシスを抑制（代償性呼吸）作用に由

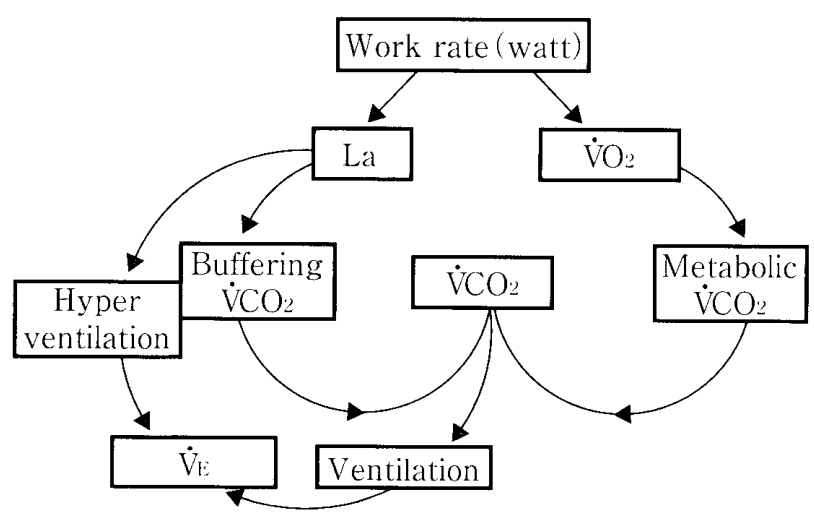

Fig 1 Concept of model: causal loop of expired gas dynamics model during incremental test I.
来する $\mathrm{V}_{\mathrm{E}}$ の增加（過換気）が引き起こされる。

\section{4. モデルの作成}

概念モデルで仮定された条件にしたがい選択し た変数は, $\mathrm{VO}_{2}, \mathrm{La}, \mathrm{VCO}_{2}$, 代謝性 $\mathrm{VCO}_{2}$ (Metabolic $\mathrm{VCO}_{2}$ ), 緩衝性: $\mathrm{VCO}_{2}$ (Buffering $\mathrm{VCO}_{2}$ ), $\dot{\mathrm{V}}_{\mathrm{E}}$, 換気 (Normal ventilation), 過換気 (Hyperventilation）の8変数に, 仕事量（Work rate）を加 えた計 9 変数であった。任事量, $\mathrm{VO}_{2}, \mathrm{La}, \mathrm{VCO}_{2}$, $\dot{V}_{1}$ の5変数を漸増負荷テストにより測定し，モデ ルに投入した。代謝性 $\mathrm{VCO}_{2}$, 緩衝性 $\mathrm{VCO}$, 換気, 過換気の 4 変数はモデル内で推定される内生変数 であった。つまり，代謝性 $\mathrm{VCO}$ は，漸増負荷テ ス卜過程において, 緩衝能が顕著に機能し始める AT以前の $\mathrm{VO}_{2}$ と $\mathrm{VCO}_{2}$ の線形関係を $\mathrm{AT}$ 以後へ 外插することにより推定した。緩衝性 $\mathrm{VCO}_{2}$ は実 测值 $\mathrm{VCO}_{2}$ と推定された代謝性 $\mathrm{VCO}_{2}$ との差によ り推定した。換気は代償性呼吸が起こる以前 (RCP 以前) の $\mathrm{V}_{\mathrm{E}}$ と $\mathrm{VCO}_{2}$ の線形関係を $\mathrm{RCP}$ 以後 へ外挿することにより推定した。過換気は実测值 $\dot{V}_{\text {I: }}$ と推定された換気との差により推定した。こ れらの外挿を用いた呼気ガス諸量の推定方法は, 矢野ら（1984）およびYano (1987）のCO excessの算出方法を応用したものである。

以上の9変数拈よび変数間の因果関係をストッ ク，フローおよびコネクタに対応させて，被験者 每に，図 2 に示されるようなフローダイアグラム （福田ら，1993）を作成した。長方形で記述され る変数がストックであり，総化事量（Total Work rate), 総 $\mathrm{VO}_{2}$ (Total $\mathrm{VO}_{2}$ ), 総 La (Total $\mathrm{La})$, 総 $\mathrm{VCO}_{2}\left(\right.$ Total $\mathrm{VCO}_{2}$ ), 総代謝性 $\mathrm{VCO}_{2}$ (Total Metabolic $\mathrm{VCO}_{2}$ ), 総緩衝性: $\mathrm{VCO}_{2}$ (Total Buffering $\left.\mathrm{VCO}_{2}\right), \dot{\mathrm{V}}_{\mathrm{E}}$ ( Total $\mathrm{V}_{\mathrm{E}}$ ), 換気 (Total Normal ventilation), 過換気 (Total Hyperventilation）は各時点に抢ける 9 变数の集積量を示す. 正呵形で記述される変数がフローであり，仕事量 (Work rate)，VO $\mathrm{VO}_{2}$ La および $\mathrm{VCO}_{2}$ などは単位 時間（1min）あたりでのストックの変化量を示 す。雲形はクラウドと呼ばれ，モデルの範国外の 環境を示す，各変数を絬ぶ単方向矢印はコネク夕 であり，変数間の因果関係を示す。 


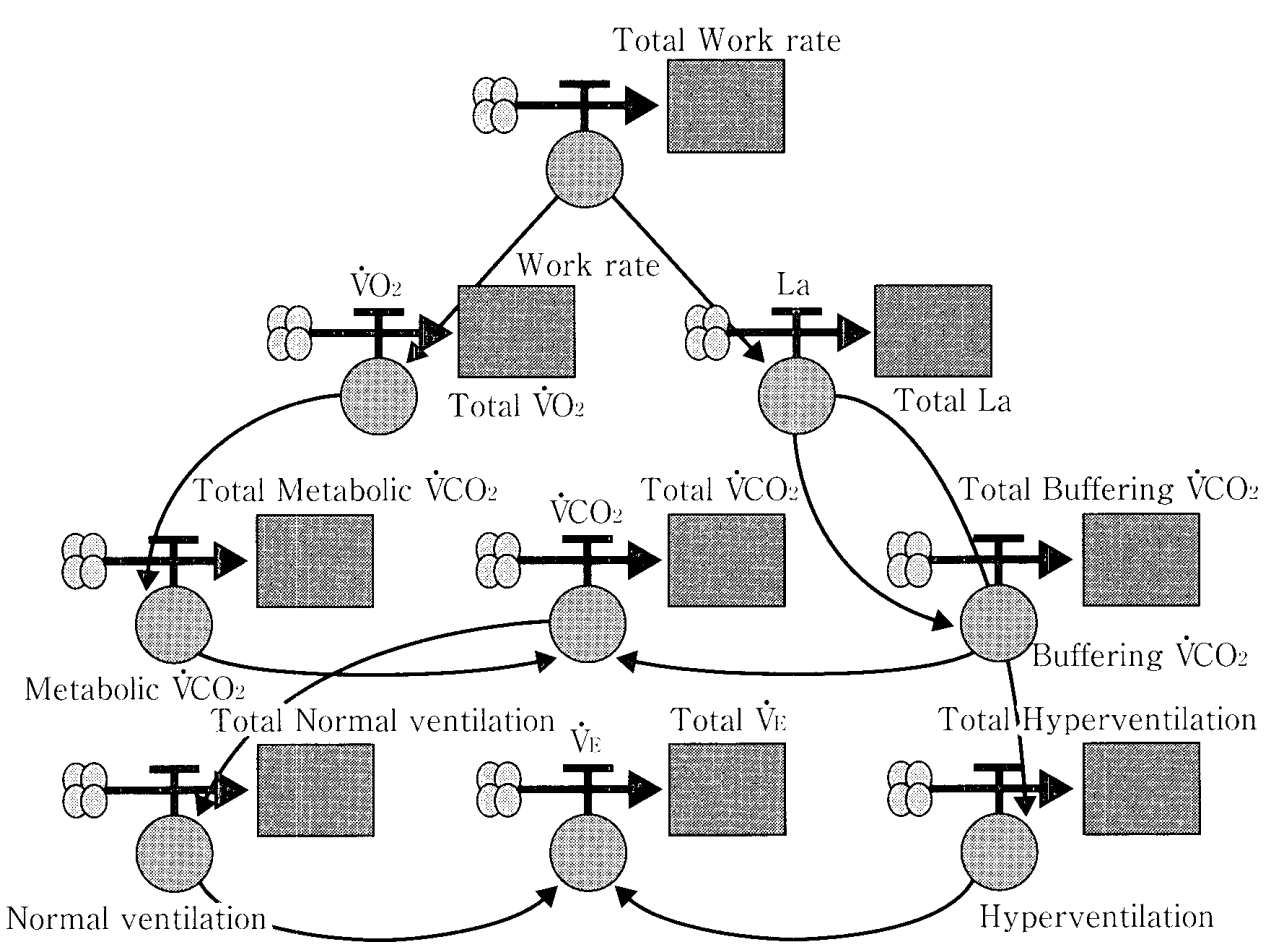

Fig 2 Flow diagram of expired gas dynamics model during incremental test using STELLA 5.1 J.

仕事量（Work rate）は時間経過に伴い1 分每: に漸増するためランプ関数（Ramp function）を 適用し，ウォーミングアップによる1分間の負街 增加の遅れをディレイ関数（Delay function）で 定義した。

Work rate $=$ Delay function (Ramp function (rate of increment, $1 \mathrm{~min}$ ), $1 \mathrm{~min}$ )

運動負荷に対する生理的応答を表す 8 変数はグ ラフ関数を用いて定義した。グラフ関数は，実測 值を用いたシミュレーションや一般的な関数を用 いて定義することが困難であるような複雑な人力 を必婹とする際に使われる機能である（森田， 1997)。 $\mathrm{VO}_{2}, \mathrm{VCO}$ あるいは Laなどの変数に対し ては指数関数など既知の関数を適用し，解析する ことが一般的であるが，運動負荷応答を表す変数 閒の関係性は個人美が大きく，関数の適合残美が 大きくなることの理由により，実测値間の関係性 を直接記述するグラフ関数（Graph function）を 用いて構造モデルを作成した。

$\mathrm{VO}_{2}$ およびLaは仕事量の増加に伴い增加する ため,グラフ関数を朋いて以下のように定義した。

$\mathrm{VO}_{2}=$ Graph function (Work rate)

$\mathrm{La}=$ Graph function (Work rate)
代謝性（Metabolic） $\mathrm{VCO}_{2}$ は $\mathrm{VO}_{2}$ の増加に刘芯 して增加し, 緩衝性 (Buffering) $\mathrm{VCO}_{2}$ は Laに より決定され， $\mathrm{VCO}_{2}$ は代謝性 $\mathrm{VCO}_{2}$ と緩衝性 $\mathrm{VCO}_{2}$ との和であることから，グラフ関数を用い て以下のように定義した。

$\mathrm{VCO}_{2}=$ Metabolic $\mathrm{VCO}_{2}+$ Buffering $\mathrm{VCO}_{2}$

Metabolic $\mathrm{VCO}_{2}=$ Graph function $\left(\mathrm{VO}_{2}\right)$

Buffering $\mathrm{VCO}_{2}=$ Graph function (La)

$\mathrm{V}_{\text {: }}$ は，それぞれ $\mathrm{VCO}_{2}$ ，Laにより決定される換 気 (Normal.ventilation) と過換気 (Hyper ventilation）の利であることから，グラフ関数を用 いて以下のように定義した。

$\dot{\mathrm{V}}_{\mathrm{E}}=$ Normal ventilation + Hyper ventilation Normal ventilation $=$ Graph function $\left(\mathrm{VCO}_{2}\right)$

Hyperventilation $=$ Graph function $(\mathrm{La})$

\section{5. 漸増負荷テスト}

自転車エルゴメー夕（モナーク社製 model $818 \mathrm{E}$ ）を用いたプロトコルの異なる多段階漸増 負荷テスト（テストI抽びテストII）を奏施し た。両テストとも，1分間の座位安静状態ののち， 1 分間のウォーミングアップ $(0 \mathrm{kp})$ を行い, 負 荷テスト中のペダル回線数を $60 \mathrm{rpm}$ 一定とした。 
テストIでは，ウォーミングアップ後 1 分間あた り $0.25 \mathrm{kp}$ ずつ，テスト IIでは $0.5 \mathrm{kp}$ ずつ負荷を漸 増させ，雨テストとも被験者が疲労困䣏に至るま で行った。テストIのデー夕を用いて呼気がス動 態モデルを作成し，テストIIのデータをモデル の妥当基準とした。

テスト中の $\mathrm{V}_{\mathrm{E}}, \mathrm{VO}_{2}, \mathrm{VCO}_{2}$ は, 自動代謝分析 装置（Mijnhardt 社 OXYCON-a）を用いて， breath by breath 法により安静時から運動終了後 まで測定した。呼気がス諸量の測定值は 30 秒毎 の平均值に換算した， La の動態を確認するため, 安静時，ウォーミングアップ終了時およびテスト 中 1 分每に耳架より採血し，採血後直ちに簡易乳 酸測定器（アークレイ社ラクテート・プロ）を用 いて Laの測定を行った。

呼気ガス諸量, 血中乳酸濃度の值から $\mathrm{VO}_{2} \max$, $\mathrm{AT}$ 時の $\mathrm{VO}_{2}\left(\mathrm{VO}_{2} \mathrm{AT}\right)$ および $\mathrm{RCP}$ 時の $\mathrm{VO}_{2}$ ( $\left.\mathrm{VO}_{2} \mathrm{RCP}\right)$ を判定した。 $\mathrm{VO}_{2} \max$ は， $\mathrm{VO}_{2}$ の增加 が前負荷段階の $150 \mathrm{ml} / \mathrm{min}$ 未満となるレベリン グオフ (leveling-off) を判定の第一基準とした (Taylor et al., 1955).レベリングオフがみられ ない場合は，呼吸交換比 1.15 以上が出現した時点 での $\dot{V O}_{2}$ とした (Tanaka et al., 1986). ATは, (1)二酸化炭素当量 $\left(\mathrm{V}_{\mathrm{E}} / \mathrm{VCO}_{2}\right)$ の変化の伴わない 酸素当量 $\left(\mathrm{V}_{\mathrm{E}} / \mathrm{VO}_{2}\right)$ の急激な増加点, (2) V-slope 法（Beaver et al.，1986）および(3)血中乳酸濃度 が安静時水準またはウォーミングアップの水準か ら急上昇する变曲点を求める両対数変換法 （Bearver et al.，1985）等から総合的に判定した。 $\mathrm{RCP}$ は 1 分間あたりの $\mathrm{VCO}_{2}$ に対する $\mathrm{V}_{\mathrm{E}}$ の比率が 増加する点と定義し（Whipp et al.，1989）， $\mathrm{V}_{\mathrm{E}}$ と $\mathrm{VCO}_{2}$ の2変量をグラフ上にプロットし，2直線回 帰法により判定した。

\section{6. シミュレーション}

シミュレーションの計算間隔は 0.1 分とし, 4 点の微係数を用いる 4 次ルンゲ・クッ夕法を用い て計算された。得られたシミュレーション結果は モデルの評価に用いた。

\section{7. モデルの評価}

モデルの再現性を検証するために，テストIの 実測值に対するシミュレーション值の相関係数を 算出した。モデルの妥当性は，テストIIの実測 值に対するシミュレーション值の適合性および等 価性により検証した.

また，システムダイナミクスを用いた全身持久 性の分析的評価を検討するため， $\mathrm{VO}_{2} \mathrm{max} / \mathrm{W}$ が 最低值を示した被験者 $\mathrm{TK} （ \mathrm{VO}, \mathrm{max} / \mathrm{W}=$ $45.7 \mathrm{ml} / \mathrm{kg} / \mathrm{min}$ ）と，最高值を示した被験者 $\mathrm{HN}$ $\left(\mathrm{VO}_{2} \mathrm{max} / \mathrm{W}=60.8 \mathrm{ml} / \mathrm{kg} / \mathrm{min}\right)$ において，シミ ユレーションにより算出された有気的および無気 的代謝を表す变数值を比較した。

モデルの適合度指標には決定係数 $\left(\mathrm{r}^{2}\right)$ を用い た。モデルの等価性指標には， $\mathrm{AT}$ 水準， $\mathrm{RCP}$ 水 準の $\mathrm{VO}_{2}, \% \mathrm{VO}_{2} \max$ ，仕事量， $\mathrm{VCO}_{2} ， \dot{\mathrm{V}}_{\mathrm{E}}$ におけ るテストIIの実測值に刘するシミュレーション 值の相関係数，ならびに対応のあるt検定による 平均値の差の検定を用いた。統計的有意水準はす べての検定で $\mathrm{P}<.05$ とした。統計処理には SPSS9.0Jを用いた。

\section{III 結果}

\section{1. モデルの再現性}

表 3 は, 被験者のテストIから得られた $\dot{V}_{\mathrm{E}}$, $\mathrm{VO}_{2}, \quad \mathrm{VCO}_{2}, \mathrm{La} の$ 実測值に対するシミュレーシ ヨン值の相関係数を示している。 $\dot{V}_{\mathrm{E}}$ では，すべ ての被験者に㧍いて $\mathrm{r}=0.999$ 以上で統計的に有

Table 2 Correlation coefficients between simulation and measurement of Test I

\begin{tabular}{lcccc}
\hline Subjects & $\dot{\mathrm{V}}_{\mathrm{E}}$ & $\dot{\mathrm{VO}}_{2}$ & $\dot{\mathrm{VCO}}_{2}$ & $\mathrm{La}$ \\
\hline $\mathrm{HN}$ & 1.000 & 1.000 & 1.000 & 1.000 \\
$\mathrm{TK}$ & 0.999 & 1.000 & 1.000 & 0.996 \\
$\mathrm{KK}$ & 0.999 & 1.000 & 1.000 & 0.995 \\
$\mathrm{RM}$ & 1.000 & 1.000 & 1.000 & 1.000 \\
$\mathrm{KJ}$ & 0.999 & 1.000 & 0.996 & 1.000 \\
$\mathrm{YY}$ & 1.000 & 1.000 & 0.998 & 0.952 \\
$\mathrm{AF}$ & 1.000 & 1.000 & 0.998 & 0.986 \\
\hline
\end{tabular}

All parameters detected significant correlation coefficient $(P<.05)$. 

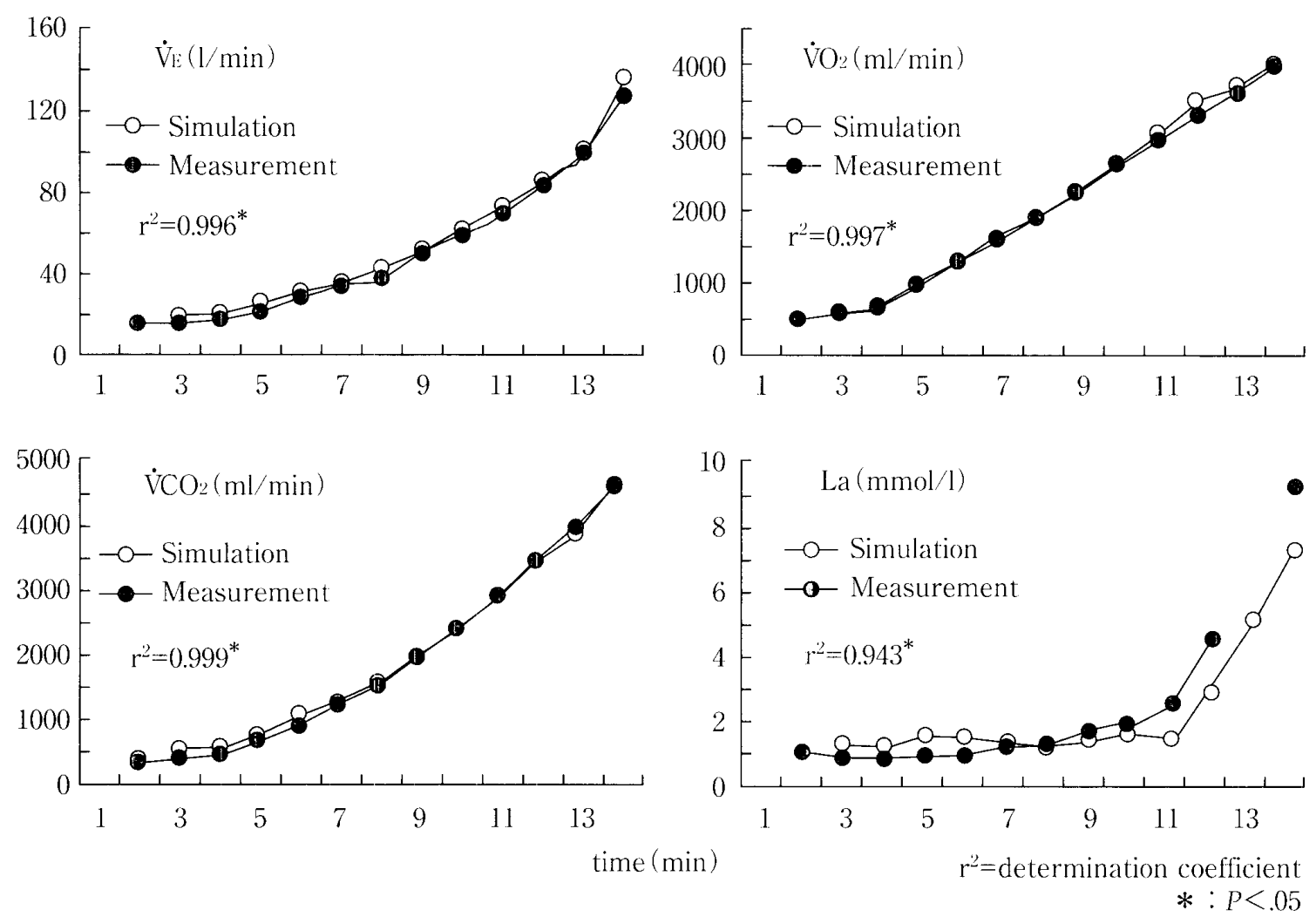

Fig 3 Fitting of simulation to measurement during incremental test II (Data of subject YY).

Table 3 Determinant coefficients of simulated expired gas parameters on the model

\begin{tabular}{lcccc}
\hline Subjects & $\dot{\mathrm{V}}_{\mathrm{E}}$ & $\dot{\mathrm{VO}}_{2}$ & $\dot{\mathrm{VCO}}_{2}$ & La \\
\hline $\mathrm{HN}$ & 0.994 & 0.998 & 0.975 & 0.972 \\
$\mathrm{TK}$ & 0.954 & 0.992 & 0.970 & 0.985 \\
$\mathrm{KK}$ & 0.985 & 0.994 & 0.969 & 0.985 \\
$\mathrm{RM}$ & 0.997 & 0.996 & 0.995 & 0.977 \\
$\mathrm{KJ}$ & 0.936 & 0.994 & 0.960 & 0.959 \\
$\mathrm{YY}$ & 0.996 & 0.997 & 0.999 & 0.943 \\
$\mathrm{AF}$ & 0.973 & 0.996 & 0.994 & 0.996 \\
\hline
\end{tabular}

All parameters detected significant determinant coefficient $(P<.05)$.

意であった。また， $\mathrm{VO}_{2}, \mathrm{VCO}_{2}, \mathrm{La}$ では，r= 0.999，0.996，0.952以上で統計的に有意であった。

\section{2. モデルの妥当性}

図 3 は被験者YYのテストIIから得られた $\mathrm{V}_{\mathrm{E}}$, $\mathrm{VO}_{2}, \mathrm{VCO}_{2}, \mathrm{La}$ の実測值に対するシミュレーシ ヨン値の適合性を示している，また，表4はすべ

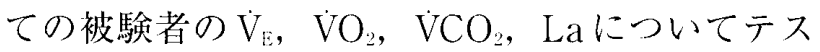
トIIの実測值に対するシミュレーション值の決
定係数を示している。すべての被験者の $\dot{V}_{\mathrm{E}}$ にお いて $\mathrm{r}^{2}=0.936$ 以上の有意な決定係数が得られた. 同様に VO 0.960，0.943 以上の有意な決定係数が得られた。

表 4 は，妥当基準である実測值から判定された AT, RCP と，シミュレーション值から判定され た AT， RCP 水準の $\mathrm{VO}_{2}$ または $\mathrm{VO}_{2} \max$ に対する 相対值， $\mathrm{V}_{1} ， \mathrm{VCO}_{2}$ および仕事量の等価性を示し ている.

$\mathrm{VO}_{2} \mathrm{AT}, \% \mathrm{VO}_{2} \max$ at AT, $\dot{\mathrm{V}}_{\mathrm{AT}} \mathrm{AT}, \mathrm{VCO}_{2} \mathrm{AT}$, Watts at ATの爱当基準に対するシミュレーショ ン值の相関係数は，それぞれ $\mathrm{r}=0.911 ， 0.948$, 0.975，0.894，0.923であった。対応のあるt検定 に扔いて $\mathrm{VCO}_{2} \mathrm{AT}$ に有意な差が認められ，その 他の項目では有意な童は認められなかった。また， VORCP, \% VO max at RCP, $\mathrm{VCO}_{2} \mathrm{RCP}$, Watts at RCPの実測值に対するシミュレーション值の 相関係数は，それぞれ $\mathrm{r}=0.944 ， 0.914 ， 0.628$ ， 0.881 であったが， $\mathrm{V}_{\mathrm{B}} \mathrm{RCP}$ では有意な相関が認め られなかった $(r=0.549)$. $\mathrm{RCP}$ 水準の备項目に 扮ける対応のあるt検定において, AT水準同様 
に， $\mathrm{VCO}_{2} \mathrm{RCP}$ に有意な差が認められ，その他の 項目においては有意な差は認められなかった。

\section{3. 呼気ガス動態の分析的評価}

図4は， $\mathrm{VO}_{2} \max / \mathrm{W}$ において評価された 2 名の 被験者についてシミュレーションによる特徴的な 呼気ガス諸量 4 変数の動態を比較したものであ
る。闭者の $\mathrm{VO}$, および代謝性 $\mathrm{VCO}$ 、は疲労困僙時 点での運動強度， $\mathrm{VO}_{2}$ および代謝性 $\mathrm{VCO}_{2}$ の值に 差があるものの，運動負荷に対する変動は近似し た傾问であった。

一方，乳酸由来の代謝性アシドーシスに抗する 緩衝能を示す緩衝性 $\mathrm{VCO}_{2}$ と過換気は異なる動態 を示した。 $\mathrm{VO}$ max/W が低值を示した被験者 TK

Table 4 Equivalence of simulated expired gas parameters at AT and RCP on the model

\begin{tabular}{|c|c|c|c|c|c|c|}
\hline \multirow{2}{*}{ Variables (unit) } & \multirow{2}{*}{$\begin{array}{c}\mathrm{r} \\
*: P<.05\end{array}$} & \multicolumn{2}{|c|}{ Simulation } & \multicolumn{2}{|c|}{ Measurement } & \multirow{2}{*}{$\begin{array}{c}\mathrm{PD} \\
*: P<.05\end{array}$} \\
\hline & & mean & SD & mean & SD & \\
\hline$\dot{\mathrm{VO}} 2 \mathrm{AT}(\mathrm{ml} / \mathrm{min})$ & $0.911 *$ & 2054.9 & 305.7 & 2072.6 & 302.2 & n.s \\
\hline$\% \dot{\mathrm{VO}} \max$ at $\mathrm{AT}(\%)$ & $0.948^{*}$ & 52.1 & 9.8 & 54.3 & 9.4 & n.s \\
\hline Watts at AT (watts) & $0.923 *$ & 162.9 & 23.6 & 158.6 & 28.5 & n.s \\
\hline$\dot{\mathrm{V} C \mathrm{O}_{2} \mathrm{AT}}(\mathrm{ml} / \mathrm{min})$ & $0.894 *$ & 1737.8 & 477.0 & 1991.0 & 311.0 & $*$ \\
\hline$\dot{\mathrm{V}}_{\mathrm{E}} \mathrm{AT}(l / \mathrm{min})$ & $0.975 *$ & 50.7 & 11.0 & 52.4 & 8.2 & n.s \\
\hline$\dot{\mathrm{V}} \mathrm{O}_{2} \mathrm{RCP}(\mathrm{ml} / \mathrm{min})$ & $0.944 *$ & 3242.4 & 327.1 & 3276.0 & 342.5 & n.s \\
\hline$\% \mathrm{VO}_{2} \max$ at RCP (\%) & $0.914^{*}$ & 81.7 & 9.3 & 85.3 & 6.7 & n.s \\
\hline Watts at RCP (watts) & $0.881 *$ & 257.1 & 23.6 & 261.4 & 22.7 & n.s \\
\hline$\dot{\mathrm{VCO}}{ }_{2} \mathrm{RCP}(\mathrm{ml} / \mathrm{min})$ & $0.628 *$ & 3165.3 & 474.7 & 3685.1 & 461.3 & $*$ \\
\hline$\dot{\mathrm{V}}_{\mathrm{E}} \mathrm{RCP}(\mathrm{l} / \mathrm{min})$ & 0.549 & 96.6 & 15.9 & 103.5 & 16.2 & n.s \\
\hline
\end{tabular}

r: correlation coefficient between simulation and measurement.

PD: paired differences on paired t-test between simulation and measurement.
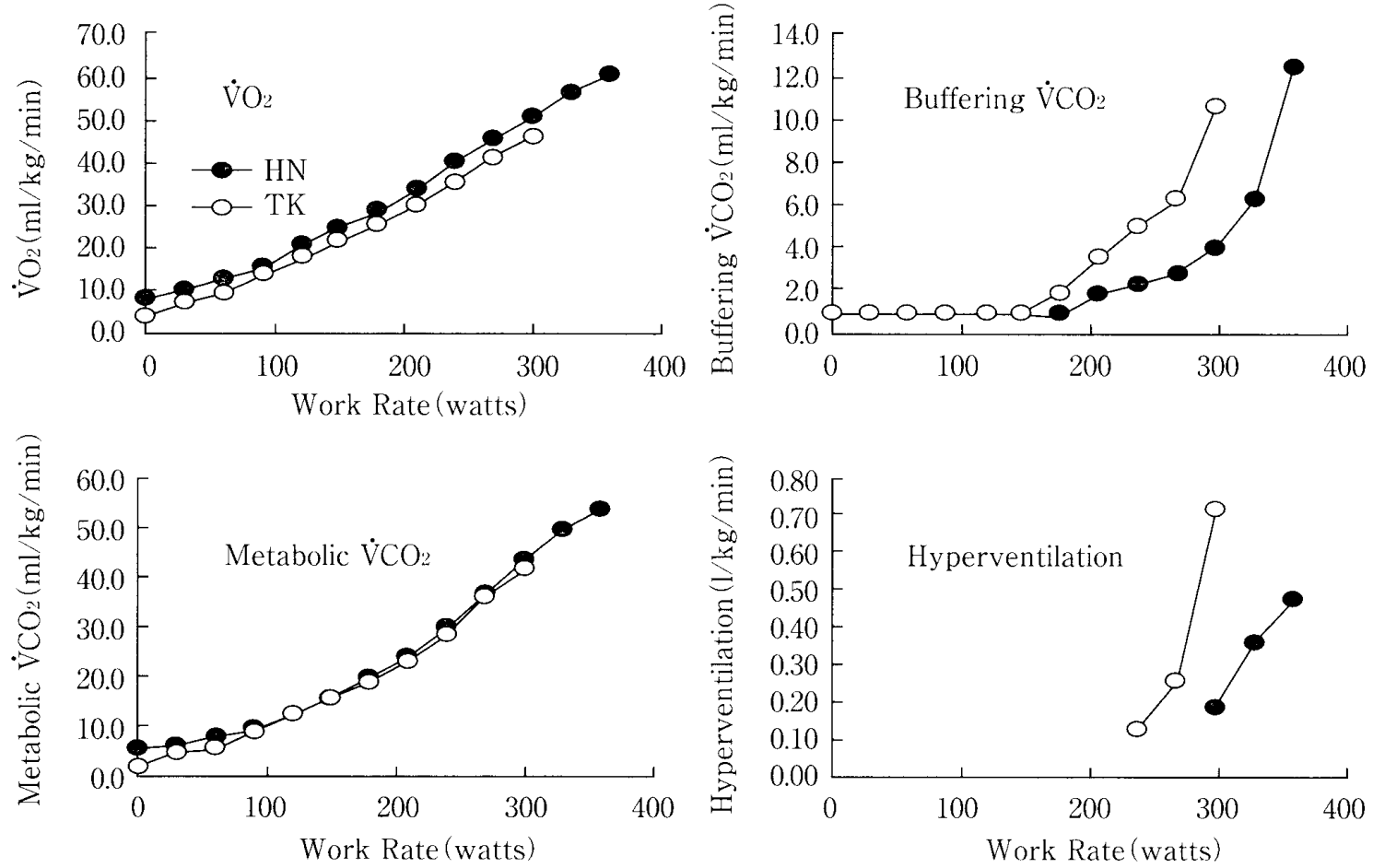

Fig 4 Comparison of Subject HN and Subject TK in specific simulated parameters (VO., Metabolic $\dot{\mathrm{V} C O}$, Buffering $\mathrm{VCO}_{2}$ and Hyperventilation). 
の緩衝性 $\mathrm{VCO}_{2}$ および過換気は，被験者 $\mathrm{HN}$ より も低い運動強度に対して増大もしくは開始寸るも のであった。被験者 TKの過換気の増大は, 被験 者HNに比べて急激な傾きを示した。

\section{IV 考察}

\section{1. システムダイナミクスモデルの妥当性}

本研究では，モデル作成に用いたテストIの実 測值に対するシミュレーション值の相関係数を用 いて，各被験者についてモデルの再現性を検証し た。各被験者ともに各変数に拈いて 0.952 以上の 有意に高い相関係数が得られた。特に $\mathrm{VO}_{2}, \mathrm{VCO}_{2}$ では $\mathrm{r}=0.998$ 以上と高く，作成されたモデルに は冓現性があることが碓認された。

モデルの爱当性は適合性と等侕性から検㹬し た. $\dot{V}_{\mathrm{k}}, \mathrm{VO}_{2}, \mathrm{VCO}_{2}, \mathrm{La} \sigma$ 決定係数 $\left(\mathrm{r}^{2}\right)$ は，そ れぞれ $0.936 ， 0.992 ， 0.960 ， 0.943$ 以上と有意に 高い適合性を示した。VO の決定係数 0.992 は， ステップ負荷テスト時の $\mathrm{VO}_{2}$ 動態に対して指数関 数モデルを適用し，非線形最小二乗法を用いてモ デリングを衍ったMorton（1987）の0.954 と同等 あるいはそれ以上に高いものであった。この結果 は，システムダイナミクスモデリングはモデルに 対する実测值の残差を最小化するモデリング手法 と同水準であり，かつ，被験者每に運動負荷過程 における呼気がス動態を記述することが可能であ

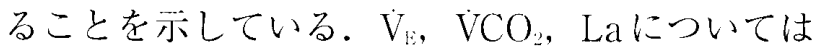
比較対象となる先行研究がないものの, 高い適合 性が得られた本研究の結果より, 各変数間の動的 な因果関倸を記述したシステムダイナミクスモデ ルの妥当性は高いと判断される。

しかしながら，本研究では 1 回の実测值を投人 してモデリングを行ったため，测定值自体の変動 に影響される。㭔気ガス諸量の测定項日は，測定 技術や测定機器によって生じる测定䛊㾤，あるい は生体本来の生物学的変動などにより奏測值が変 動することが知られている (Morgan and Mitchell，1992)。したがって，今後は测定愦美 㧍よび生物学的詥差を最小にするため, 策用的に 可能であれば測定を複数回実施し，その平均值を
用いたモデリングの検討が必要であると考えられ る.

AT， RCP雨水準に打汀る相関係数は， $\mathrm{V}_{\mathrm{E}} \mathrm{RCP}$ を除く $(r=0.549, P>.05)$ ， すべての項目で中 等度から高い相関を示し，特に，VO,AT， $\mathrm{VO}$ RCP, \% VO max at AT, \% VO max at RCP, Watts at ATおよびWatts at RCPではr $=0.911$ 以上の非常に高い相関が認められ，また，妥当基 準とシミュレーション值の平均值間に有意な差は 認められなかった。これらの絬果から，モデルは 等㑣性があると判定された。

一方， $\quad \mathrm{VCO}_{2} \mathrm{AT}, \quad \mathrm{VCO}_{2} \mathrm{RCP}$ は有意な相関は示 したものの $\left(\mathrm{VCO}_{2} \mathrm{AT} ： \mathrm{r}=0.894, \quad \mathrm{VCO}_{2} \mathrm{RCP}\right.$ : $r=0.628$ ，妥当基準とシミュレーション值間に 有意な港がみられた（ $\mathrm{VCO}_{2} \mathrm{AT} ：$ paired differences mean $=254 \mathrm{ml} / \mathrm{min}, \quad \mathrm{VCO} R C P:$ paired differences mean $=520 \mathrm{ml} / \mathrm{min}) . \mathrm{V}_{1} \mathrm{RCP}$ では妥 当基準とシミュレーション值間に有意な差は認め られなかったものの，雨群間に有意な相関も認め られなかった。これらの結果から， AT, RCP水 準の $\mathrm{V}_{1} ， \mathrm{VCO} に$ において，モデルは十分な等㑣性 を有するとは言い難い。

Newstead et al.（1990）は， $\dot{V}_{\text {: }}$ 拈よび $\mathrm{VCO}_{2}$ の 変動は動脈血カリウムイオン $(\mathrm{K}+)$ の変動と一 致していることから, $\mathrm{K}+$ も換気高進の要因の 1 つである可能性を示唆している. Miyamura et al.（1998）は， $\dot{V}_{\mathrm{E}}$ 高進させる要因として $\mathrm{H}+$, $\mathrm{K}+$ の他に，カテコラミンや体温などがあり，抑 制する因子としてドーパミンを示している。この ように， $\dot{V}_{\mathrm{E}} や \mathrm{VCO}_{2}$ を規定する要因は多く，関係 性が複雑であることを考慮すると, 本研究のモデ ルには念まれない他の要因の影響も考えられる。 しかしながら，本研究で用いた代謝性指標 $\mathrm{AT}$, $\mathrm{RCP}$ の判定方法は $\mathrm{VO}_{2}$ 動態に対する $\mathrm{VCO}_{2}$ 動態 (Beaver et al.，1989)，および $\mathrm{VCO}_{2}$ 動態に対す る $\dot{V}_{\mathrm{E}}$ 動態を評㑛したものである（Whipp et al., 1989)。そのため，シミュレーション值により判 定された VOAT，VORCP，\% VOmax at ATお よび\% VOmax at RCPが妥当基準に対する有意 な等価性を示し， $\mathrm{V}_{\mathrm{E}}, \mathrm{VCO}_{2}$ の高い適合性を示し たことから， $\mathrm{VO}_{2}, \dot{\mathrm{V}}_{\mathrm{E}}$ 扩よび $\mathrm{VCO}_{2}$ 動態に刘する 
本システムダイナミクスモデルは妥当であると判 定された。

\section{2. システムダイナミクスモデリングを用いた 分析的な全身持久性評価方法}

全身持久性の評価基準である $\mathrm{VO}_{2} \mathrm{max} / \mathrm{W}$ にお いて最低值および最高值を示した 2 名の被験者を 用いて，システムダイナミクスモデリングを用い た全身持久性の分析的評価を検討した。2名の $\mathrm{VO}_{2}$ および代謝性 $\mathrm{VCO}_{2}$ の動態は互いに直線的で あり，その傾きは拉およそ同等であることが視覚 的に認められるこのことから，雨者の運動に対す る有気的代謝の反応は同様であると考えられる。 したがって，疲労困䣏時点での代事量および $\mathrm{VO}_{2} \mathrm{max} / \mathrm{W}$ にみられる両者の成績の差は有気的 代謝に起因するものではないと考えられる，有気 的代謝の動態は再者において同水準であったのに 対して, 緩衝性 $\mathrm{VCO}_{2}$ および過換気の動態は被験 者 HNがTKより高い運動強度から増加（右傾化） する傾向であった。この結果は，被験者間におけ る緩衝能もしくは無気的代謝の優劣を示すもので あると解积することができる。

$\mathrm{VO}_{2} \max$ の制限因子は外的要因と内的要因に分 類される. 外的要因は $\mathrm{VO}_{2} \max の$ 測定に用いる運 動様式や低酸素環境などであり, 内的要因には循 環機能, 筋での酸素消費能が挙げられる。これま での研究成果から，筋での酸素消費能をその決定 因子とみなすことが多い（山地，1992）。AT以 上強度での運動中に過剩に蓄積する Laは筋の運 動を阻害する要因（代謝性アシドーシス）であり， 緩衝能はそれに抗する能力である。これらのこと を考慮すると，仕事量に対する有気的代謝の変動 は2名の被験者とも近似していたものの，連動の 継続時間, 疲労困䣏時の仕事量, $\mathrm{VO}_{2} \max$ に差が 見られるのは，被験者 TKの方が緩衝能が劣り， 筋収縮の低下やそれに伴う酸素消費の減少に起因 すると推察される。このように，システムダイナ ミクスモデリングでは各機能の動的因果関倸を構 造的に取り扱うために，各個人の全身持久性につ いてより分析的な評洒が可能である。

本研究では被験者間で比較検討を行ったが，シ
ステムダイナミクスモデリングを用いた全身持久 性の評価方法は個体内での比較にも適用可能であ る。すなわち，トレーニング前に漸増負荷テスト を実施し，モデルを作成し，トレーニング後，同 一の漸增負荷テストを実施し，モデルによるシミ ユレーション值とトレーニング後の実測值の隔た りを発達として捉えることができる，システムダ イナミクスモデルは現象の動的因果関係を構造的 に取り扱うため，トレーニングの効果として，ど の機能に発達が見られたかを分析的に確認するこ とが可能である。トレーニングによる発達は個別 性が大きいことから，漸増負荷テストとシステム ダイナミクスモデリングを用いた全身持久性の評 优方法は有用性の高いものであると考えられる。

本研究では，システムダイナミクスモデリング の手続きに従い， $\mathrm{VO}_{2}, \mathrm{La}, \mathrm{VCO}_{2}$, 代謝性 $\mathrm{VCO}_{2}$, 緩衝性 $\mathrm{VCO}_{2}, \dot{\mathrm{V}}_{\mathrm{E}}$ ，換気，過換気，運動強度の 9 項目を構成要素として，各個人について漸増負荷 テスト過程における呼気ガス諸量間に見られる動 的因果関係モデルを構築した。適合度指標である 決定係数は $\mathrm{V}_{\mathrm{E}}, \mathrm{VO}_{2}, \mathrm{VCO}_{2}$ および $\mathrm{La}$ の各項目に おいて有意に高い值を示した。また，AT， RCP 水準の $\mathrm{V}_{\mathrm{F}}, \mathrm{VCO}_{2}$ においては十分な等価性は認め られなかったものの， $\mathrm{AT} ， \mathrm{RCP}$ 水準の $\mathrm{VO}_{2}$ ， $\mathrm{VO}_{2} \max$ に対する $\mathrm{VO}_{2}$ の相対值および運動強度に おいて有意な高い等価性が検証された。これらの 結果より，本研究において構築されたモデルの妥 当性が検証された。システムダイナミクスモデリ ングを適用することによって，運動負荷過程にお ける生理的指標間の動的因果モデルを個々人につ いて構築することができることから，全身持久性 の分析的評価およびトレーニング效果の分析的評 価の可能性が示唆された。本研究では漸増負荷テ スト過程のみを検討したが，対象者のトレーニン グ手段に適合した呼気ガス動態モデリングを実施 するためには，定常負荷運動や間欠負荷運動など の様々な連動負荷様式におけるシステムダイナミ クスモデリングの適用可能性，さらに仕事量の変 動と呼気ガス動態間にフィードバック関係を仮定 したより柔軟性のあるモデルについての検討が今 後の課題として残されていると思われる.また， 
本研究に打ける標本数は 7 名であり，標本による 結論の一般化に制限を与える要因の一つ（標本に よる研究の限界）であると考えられる。平均值の 差の検定㧍よび相関係数の有意性検定における統 計的過䛊を回避し，検定の頑健性を確保するため には多数の標本を用いた検討も必要である.

\section{文献}

Beaver, W.L., Wasserman, K., and Whipp. B.J. (1985) Improve detection of lactate threshold during exercise using a log-log transformation. J. Appl. Physiol. 59: $1936^{-1940 .}$

Beaver, W.L., Wasserman, K., and Whipp, B.J. (1986) A new method for detecting anaerobic threshold by gas exchange. J. Appl. Physiol. 60: 20-27.

Billat, V.L., Bocquet. V., Slawinski, J., Laffite, L., Demarle. A.. Chassaing, P., and Koralsztein. J.P. (2000) Effect of a prior intermittent run at $\mathrm{VO}$ max on oxygen kinetics during an all-out severe run in humans. J. Sports. Med. Phys. Fitness. 40: 185-194.

Bowker, D.W. (1993) Dynamic models of homogeneous systems. In: Fry, J.C. (Eds) Biological data analysis: a practical approach. Oxford. Univ. Press: New York, pp. 313-343.

Cabrera, M.E. and Chizeck, H.J. (1996) On the existence of a lactate threshold during incremental exercise: a systems analysis. J. Appl. Physiol. 80: 1819 $-1828$.

Di Prampero, P.E. (1981) Energetics of muscular exercise. Rev. Physiol. Biochem. Pharmacol. 89: 143222.

福田 敦・小山茂・蓸 朝草・武田晋一 (1993) システムダイナミクスの基碟。国際システムダイ ナミクス日本支部編STELLA II 入門テキスト。バ ーシティーウェーブ：東京, pp. 1-21.

Hughson, R.L., Sherrill, D.L., and Swanson, G.D. (1987) Kinetics of $\mathrm{VO}_{2}$ with impulse and step exercise in man. J. Appl. Physiol. 64: 451-459.

Hughson, R.L., Winter, D.A., Patla, A.E., Swanson, G.D., and Cuervo, L.A. (1990) Investigation of $\mathrm{VO}_{2}$ kinetics in humans with pseudo random binary sequence work rate change. J. Appl. Physiol. 68: 796 -801 .
McArdle, W.D., Katch, F.I., and Katch, V.L. (1991) Exercise Physiology; Energy, Nutrition, and Human Performance (3rd ed), Lea \& Febiger: Philadelphia. Miyamoto, Y. and Niizeki, K. (1992) Dynamics of ventilation, circulation, and gas exchange to incremental and decremental ramp exercise. J. Appl. Physiol. 72: 2244-2254.

Miyamura, M., Ishida, K.. Itoh, H., and Ohkuwa, T. (1998) Relationship between maximal pulmonary ventilation and arterialized venous blood potassium and dopamine concentrations obtained at exhaustion in man. Jpn.. J. Physiol. 48: 17-23.

Morgan, D.W. and Mitchell, C. (1992) Physiological aspects of running economy. Med. Sci. Exerc. 23: 378 -383 .

森田道也（1999）経営システムのモデリング学習. 牧野書店：東京, pp. 65-71.

Morton, R.H. and Gregory, C.G. (1987) A systems model approach to the ventilatiory anaerobic threshold. Eur. J. Appl. Physiol. Occup. Physiol. 56: 367-373.

Newstead, C.G., Donaldson, G.C., and Sneyd, J.R. (1990) Potassium as a respiratory signal in humans. J. Appl. Physiol. 69: 1799-1803.

Sherrill, D.L., Anderson. S.J., and Swanson, G.D. (1990) Using smoothing splines for detecting ventilatory thresholds. Med. Sci. Sports. Exerc. 22: 684-689.

鳥田俊郎・山内 炤（1994）システムダイナミクス 入門. 鳥田俊郎編 日科技連出版社：東京，pp. 351.

清水和幸（1999）生命システム解析のための数学. コロナ社：東京, pp. 95-109.

Tanaka, K., Watanabe, H., Konishi, Y., Mitsuzono, R. Sumida. S., Tanaka, S., Fukuba. T., and Nakadomo, F. (1986) Logtitudinal associations between anaerobic threshold and distance running performance. Eur. J. Appl. Physiol. 55: 248-252.

Taylor, H.L., Busirk, E., and Henschel, A. (1955) Maximal oxygen uptake measure of cardio-respiratory performance. J. Appl. Physiol. 8: 73-80.

山地啓司（1992）最大酸素掑取量の科学。杏林書 院：東京, pp. 208-225.

矢野德郎 - 浅野勝已 - 野村武男 - 松阪 晃 - 平木場 浩二（1984）漸増運動時の $\mathrm{VCO}_{2}$ の動態. 体力科学 
33: $201-210$.

Yano, T (1987) The differences in $\mathrm{CO}_{2}$ kinetics during incremental exercise among sprinters, middle, and long distance runners. Jpn. J. Physiol. 37: 369-378.

Wasserman, K., Beaver, W.L., and Whipp, B.J. (1986) Mechanisms and patterns blood lactate increase during exercise. Med. Sci. Sports. Exerc. 18: 344352.

Whipp, B.J. and Wasserman, K. (1972) Oxygen up- take kinetics for various intensities of constantload work. J. Appl. Physiol. 33: 351-356.

Whipp, B.J., Davis, J.A., and Wasserman, K. (1989): Ventilatory control of the 'isocapnic buffering' region in rapidly-incremental exercise. Respir. Physiol. 76 : $357-367$.

平成 14 年 1 月 16 日受付) 平成 14 年 9 月 7 日受理 